\title{
Impact of Foreign Investment in the Yemen's Economic Growth: The Country Political Stability as a Main Issue
}

\author{
Anwar Salem Musibah ${ }^{1}$, Arfan Shahzad ${ }^{1} \&$ Faudziah Hanim Bt Fadzil $^{1}$ \\ ${ }^{1}$ Othman Yeop Abdullah Graduate School of Business, University Utara Malaysia, Malaysia \\ Correspondence: Anwar Salem Musibah, Othman Yeop Abdullah Graduate School of Business, University Utara \\ Malaysia, Malaysia. Tel: 60-17-511-4174. E-mail: asomm78@yahoo.com
}

Received: July 19, 2014 Accepted: November 16, 2014 Online Published: January 14, 2015

doi:10.5539/ass.v11n4p102

URL: http://dx.doi.org/10.5539/ass.v11n4p102

\begin{abstract}
This paper investigates the moderating role of political stability in the Foreign Direct Investment (FDI) inflows into Yemen over the last two decades. Augmented Dickey Fuller (ADF) test was employed to check the stationary of the data. Following the ADF test, the standard and hierarchal regression approaches were used for the analysis. The standard regression results show that the GDP growth rate has significant negative effects on FDI inflows into Yemen while exchange rate, inflation rate, balance of payment, and gross national income have no effect on the FDI inflow in the country. However, when the moderating variable, political stability is used together with other variables such as exchange rate, inflation rate, balance of payment and gross national income, the results of hierarchical regression indicate that these variables are important determinants of FDI inflows into the country. Therefore, the results suggest that political stability is critical for the future growth of Yemen economy.
\end{abstract}

Keywords: FDI inflows, political stability, gross national income, GDP growth rate, hierarchical regression, Yemen

\section{Introduction}

It has been extensively known in theory and practice that foreign direct investment in a country often leads to many economic advantages such as foreign exchange improvement, technology transfer, organizational framework and managerial skills, improvement in the balance of payment, job creation and promotion of the export of the countries (Shahzad et al., 2013; UNCTAD, 2011; Crespo \& Fontura, 2007; Gorg \& Greenaway, 2004; Brooks et al., 2003). Few famous economists have claimed that FDI can also lead to the maximization of domestic investment via its linkages (both forward and backward) in the process of encouraging both innovation and economic growth of the country (Badr \& Ayed, 2015; Musibah et al., 2014; Omri \& kahouli, 2014; Temiz \& Gokmen, 2014; Shahzad et al., 2013; Awan et al., 2011; Brooks et al., 2003)

The financial and economic systems integration through social and cultural aspects in a phenomenon known as globalization has transformed the world into a small village. Globalization has introduced opportunities for success, but the inherent risks associated with it have also been multiplied. In the context of the financial system, foreign direct investment (FDI) is deemed to be the core globalization component (Cho, 2004). In other words, FDI is referred to as the core globalization element in the global economy (Anyanwu, 2012). It consists of the stock purchases, earnings reinvestment, and lending of funds to a foreign subsidiary or a foreign branch (Duce, 2003). Overall, the FDI inflow is significantly to the developed and developing nations as extensively acknowledged in literature dedicated to economics. Over the last ten years of the $20^{\text {th }}$ century, FDI inflows have shown an increasing trend that doubles that of the world economy, trade flows (Rajana et al., 2008; Sinani \& Meyer, 2004). The FDI contribution to the host country's national economy is expected to positively influence the employment opportunities, improve the managerial productivity of capital in the industrial sector, increase foreign trade and economic growth with the corresponding increase in technology shift (UNCTAD, 2011; Ifaro et al., 2004). The FDI benefits of the economy of the host country further facilitate the superior utilization of available raw resources, improve management and marketing methods, provide access to up-to-date technologies, and improve human capital via job training and HRM strategy. Aside from the above, foreign money inflows reserves can be used to finance current account trade deficits of balance of payments. Contrary to the external debt, money inflows via FDI do not entail debt redemption and interest liabilities. In the past years, several 
developing nations have established sweeping reforms towards liberalization and these have led to dynamic competition among these countries on the global level.

Entry barriers and control laid down on the business activities of foreign entry in these countries are eradicated to pave way for specific incentives and business facilitating policies like tax rebates, export zones creation, among others.

A dynamic competition for the FDI inflows attraction exists among developing countries as novel challenges are encapsulating growth opportunities under the $21^{\text {st }}$ century economic dynamism.

Moreover, developing countries are providing incentive packages to attract foreign investors. Countries, the world over are attempting to enhance the basis of their economic to cost on their macroeconomic policies (UNCTAD, 2010; Pajunen, 2008). Many researchers have analyzed the role of FDI in the growth of several economies to investigate the investment-growth relations. It is assumed that FDI is a significant source for obtaining capital, up-to-date technology, managerial skills, enhanced marketing know-how and output for current exports. The FDI-trade relationship is characterized by two main channels in the host country. First, countries having great degrees of openness are ostensibly attracting more FDI inflows. Technically, the openness degree is gauged via trade GDP ratio. Second, the FDI inflows can impact the trade flows via technology transfer and expansion of industrial output in the export sector (Chowdhury \& Mavrotas, 2006).

As previously mentioned, FDI is extensively acknowledged as a primary basis of foreign investment in high tech industries and growth process in the context of an under developing country, and thus, it is considered to be the driver of economic growth in the global level. This holds true for both IMF and the World Bank who also advocate that FDI is a vital source of the development process, planning and programming of developing country under the aim of the $21^{\text {st }}$ century globalization. Based on the World Investment Report (WIR) annually published by UNCTAD, the role and issues concerning FDI inflows in the world economy have been time and again examined. Accordingly, based on the WRI issues report, it is significant to conduct a review of the growth trend exhibited by FDI inflows and outflows in the global economy and major global economic units, like developed and developing economies. In the past twenty years, the growth of FDI on a global scale and its economic significance have been distinct and expedient compared to trade flows, particularly in the world's topmost superior industrial economies such as developed and developing economies as reported in Table 1.

Table 1. Worldwide FDI during the period of 2000-2013

\begin{tabular}{lllllll}
\hline Year & World & Developing Economies & Developed Economies & MENA & GCC & Yemen \\
\hline 2000 & $1,418,788$ & 192,178 & $1,226,610$ & 12,594 & 391 & 6 \\
2001 & 839,780 & 193,559 & 646,221 & 11,656 & 1,957 & 155 \\
2002 & 625,815 & 173,726 & 452,089 & 11,786 & 1,515 & 114 \\
2003 & 598,860 & 183,285 & 415,574 & 20,660 & 6,134 & -89 \\
2004 & 733,597 & 280,770 & 452,827 & 29,500 & 14,145 & 144 \\
2005 & 986,853 & 328,655 & 658,197 & 53,142 & 28,318 & -302 \\
2006 & $1,474,955$ & 440,201 & $1,034,754$ & 84,936 & 39,232 & 1121 \\
2007 & $1,999,074$ & 607,681 & $1,391,393$ & 90,183 & 48,405 & 917 \\
2008 & $1,817,004$ & 742,906 & $1,074,098$ & 107,601 & 61,698 & 1554 \\
2009 & $1,216,805$ & 535,798 & 681,007 & 87,110 & 51,441 & 129 \\
2010 & $1,411,137$ & 587,632 & 823,505 & 73,200 & 41,258 & 189 \\
2011 & $1,654,283$ & 706,035 & 948,248 & 54,497 & 26,275 & -518 \\
2012 & $1,353,930$ & 671,825 & 682,105 & 62,553 & 26,368 & -529 \\
2013 & $1,451,676$ & 733,135 & 718,541 & 103,278 & 23,888 & -133 \\
\hline
\end{tabular}

Sources: Foreign Direct Investment Inflows: UNCTAD 2013.

As noted, the majority of the studies have concentrated in certain regions and countries. For example, Mhlanga, Blalock \& Christy (2010) on the Southern African Development Community, Vijayakumar, et al., (2010) on BRICS, Mohamed \& Sidiropoulos (2010) on the Middle East, North African (MENA) countries, Kumar \& Chadha (2009) on India, Cheung \& Qian (2009) on China, Asiedu (2006) focused on Sub-Saharan Africa (SSA) and Deichmann, Karidis \& Sayek (2003) on Hungary, Poland and the Baltic region. In studies providing 
extensive analysis, the SAARC region covering Pakistan, Sir Lanka, India, Nepal and Bangladesh has received the least attention. Only a very few studies has covered a wider range of countries and determinants. In the Middle east region covering Yemen, Saudi Arabia, Iraq, Egypt, Syria, United Arab Emirates , Jordan , Palestine, Lebanon, Oman, Kuwait, Qatar , and Bahrain, least attention has been paid by the researchers to provide a comprehensive analysis.

Developing countries are interested in attracting FDI for many reasons. Several developing nations such as Yemen have been facing challenges in terms of closing the saving-investment gap and FDI can impact the boost the economic growth by reducing this gap, facilitating new technology relocation into the country, creating jobs for the nation and expanding national output and growth level (Kobrin, 2005; Ataullah et al., 2004). Given the advantages attributed to the employment of foreign capital in the process of developing nations, such nations are inclined to liberalize their FDI policies for the maximization of FDI inflows. On the whole, empirical analysis and theories however have resulted in mixed findings regarding the impact of FDI on economic growth in these countries. In the past twenty years, FDI exhibited a monumental expansion of inflows and outflows on a global level. The global FDI inflows are approximated to be about 4.4\% for 2011 (UNCTAD, 2011).

Every nation attempts at seeking greater inflows of FDI in order to benefit from the expected advantageous effects on output production for the capital inflows, advancement of technology, management expertise, and market know-how.

In spite of the fact that Yemen is a country still undergoing a low level of FDI inflows, the Yemeni government has shown considerable interest in attracting FDIs over the past years. The Central Bank of Yemen's (CBY, 2008) report described Yemen as one of the poorest nations in the Middle East, with approximately $35 \%$ of its population living below the poverty line and with a GDP of 5.6\% as at 2005 because of increased production of oil by $4 \%$ in 2004 . However, such growth rate decreased to $3.2 \%$ and remained at $3.3 \%$ in 2007 due to decrease in the production of oil. During the following year, the GDP increased to $3.9 \%$ and in 2009, the move towards initiating a new liquefied natural gas project was expected to bring about a greater increase in the production of hydrocarbon. By 2010, the real GDP increased to 7.7\% (CBY, 2010) but declined rapidly in 2011 to a lowest level of $-12.7 \%$. This could be due to the suffocating political crisis experienced by the Middle East countries. However, there was slight improvement in the real GDP in the following year 2012, 2013 as it increased by $2.4 \%$ and $6 \%$ respectively (UNCTAD, 2013).

With regards to its macroeconomic stability, Yemen is among the several countries that have launched reformation programs which led to the occurrence of many controversies. This includes the plan to manage the exchange rate floating. The Yemeni exchange rate experienced a dynamic fluctuated in the past twenty years. The Central Bank of Yemen (CBY) established a floating rate system in 1996 but has an evident preference for the stable Yemeni Rial (Schneider et al., 2007). With regards to the rate of inflation, Yemen is one of the nations that reported the highest price increase in the Middle Eastern region in 2008. More specifically, it reported a high and volatile rate of inflation from 2002 to 2007 (Almounsor, 2010).

The government of Yemen has made great efforts via legal framework and promotional campaigns to attract foreign investors. It made its first step in attracting FDI inflows by establishing the Yemeni General Investment Authority in 1992 and passed the Foreign Investment Law. In order to further encourage FDI, a new Foreign Investment Law was also issued in 2002. Additionally, it established a specific center to lower the time required to approve and register investments (UNCTAD, 2009). The country has also introduced other incentives to motivate FDI flows. Currently, the Yemeni government permits $100 \%$ foreign ownership, and provides income tax holidays and exemptions to import duty. Furthermore, incentives in the form of free zone, including tax profits exemptions could be allowed for 15 years with a potential extension for an additional decade.

Also, in Yemen, the private sector of foreign direct investment can play a positive role in the economic growth and development of the country. The Yemen government is playing a strategic role in attracting the flows and corresponding benefits of foreign aid. Foreign direct investment in the private sector of the country is seen to be of low order. To this extent, this study investigates the determinants of FDI inflows in the context of Yemen. With considerations of all such significant facets of the envisaged investigation of the FDI issues relating to Yemen, by and large, the present study will focus on the relationship among macroeconomic determinants, business environment on the FDI inflows and political stability.

\section{Motivation of the Study}

Several countries have experienced a considerable FDI increase owing to its significant impacts on developed and developing nations. Nevertheless, in Yemen, low levels of FDI inflows have been experienced and the country is considered as one of the countries having the least amount of FDI inflows in the Middle East, as 
presented in Figure 1.

In the context of Yemen, the Inward FDI Potential Index is lower than its Inward FDI Performance Index and according to UNCTAD (2007), Yemen is among the under-performing nations. In 2008, UNCTAD stated that Yemen was among the nations that were performing lower than their potential and suggested that Yemen should engage in considerable reforms to encourage its investment environment and its share of total FDI inflows.

By 2009, UNCTAD revealed that Yemen still had low levels of FDI inflows and on top of this, its FDI inflows experienced sharp decline and had been negative for some years. This indicates repatriations of prior investments in years by foreign investors. Moreover, the General Investment Authority in Yemen reported that from 1992 to 2008 , approximately $27 \%$ of the registered investment failed and foreign investments constituted the greatest portion of these failures.

UNCTAD highlighted the country's negative value of Inward FDI and attributed it to foreign investors' disinvestment. Specifically, Yemen had a negative value from 1995 to 2000, and also in 2003, 2005,2011 and 2012. In 2013, FDI inflows in Yemen improved slightly to 560,268 YR million but remained negative.

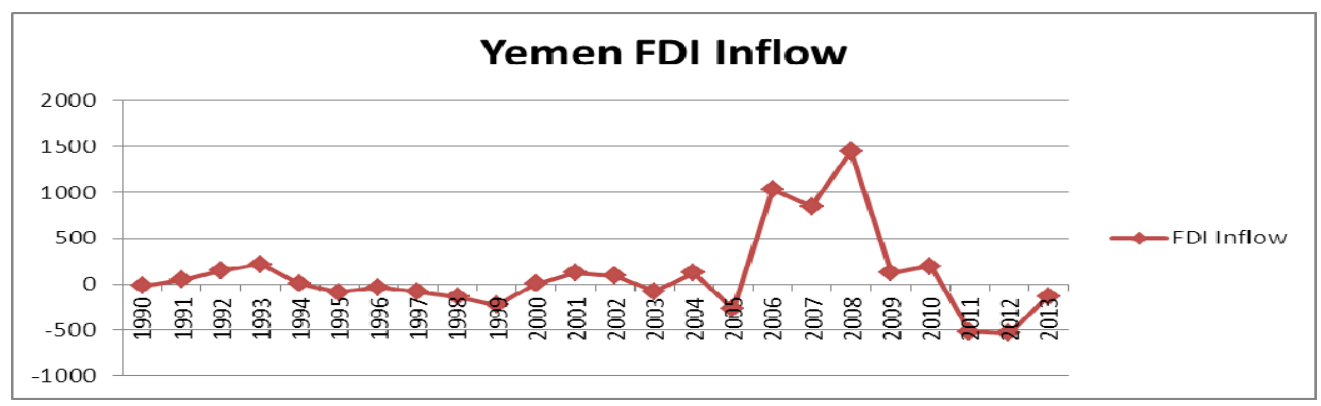

Figure 1. Yemen FDI inflow during the period 1990-2013

Source: UNCTAD, World Investment Reports, 2013

The notable low FDI and its weak contribution to the economic growth in Yemen can be explained by the international reports such as UNCTAD (2013) and World Bank (2013). Such reports confirm the undesirable effect of poor exchange rate and GDP, and corruption on the FDI inflows in Yemen. Many reasons have also been suggested for this weak contribution by the previous studies (Hela \& Bouras, 2014; Musibah et al., 2014; Shahzad \& Al-Swidi, 2013; AL-Shebami et al., 2013; Shahzad et al., 2012; Almsafir et al., 2011; Mahdi et al., 2011; Chami et al., 2007; Omran \& Bolbol, 2003) to include the following:

1) Lack of attention placed on improving the level of openness in Yemen;

2) Oversight of the key role of the macroeconomic policy in obtaining FDI;

3) Lack of political stability to improve and reinforce FDI inflows;

4) Lack of attention placed on the business environment for the attraction of the expected degree of FDI inflows;

5) Outdated infrastructure;

6) Increasing degrees of corruption that leads to negative effects on FDI inflows in the country.

Many studies have been dedicated to the examination of the role of FDI for economic growth and the integrated determinants of FDI attraction. Generally speaking, studies have contended that FDI plays a key role in the economic growth of the country. According to Thamos et al. (2008), foreign associates of TNCs (Transnational Corporations) perform when it comes to new product development and technology adoption compared to local firms and hence, using modest competitive pressure and encouraging local firms to imitate and transform. A review of literature concerning the relationship between variables, including corruption index, business environment, political stability, and the FDI inflows reveals mixed findings. To begin with, Akcay (2001) finds no negative evidence between corruption and FDI while Habib \& Zurawicki (2002) have, however, indicated that there is a negative impact of corruption on FDI. In the examination of the effect of political instability on the FDI inflows, mixed findings have also been reported. For example, Wheeler \& Mody (1992) and Singh \& Jun (1999) report that political instability and administrative efficiency significantly impact FDI inflow. Many other studies (Younis et al., 2008; Shahzad et al., 2012) on the other hand, have established that political instability have significant impact of FDI inflow. Because investors are sensitive to the political stability of the countries, it 
is assumed that the political stability can assist in attracting FDI inflows. Other researchers like; Madani, S., and Nobakht, M.(2014) Schneider and Frey (1985) and Kim (2010) state that PS that is open and welcoming to foreign investments reveals that property rights and civil rights have key role to play in the attraction of FDI into the country.

Accordingly, this study attempts to explain the issues of academic interest and to shed light on the major FDI determinants by examining some macroeconomic variables and the business environment in light of Yemen's political situation and policy making on its FDIs. This study attempts to investigate the impact of business environment's macroeconomic factors in terms of various political regimes on the country's capability of attracting FDI inflows.

\section{Determinants of FDI Inflows}

FDI is commonly defined as a cross-border investment made by an enterprise directly in a production facility and/or in the marketing of a product. The investment is made to get a lasting interest in a foreign enterprise abroad. Dunning (1988) defines FDI to be an activity which is controlled and organized by companies in host countries. Bitzenis (2007) concludes that the "key features of the FDI are investing, acquiring and obtaining a foreign firm or asset and influencing/controlling the management operations".

In a related study, Wang (2009) examines inward FDI and growth of economies in several Asian countries for the period 1987-1997. The research obtains mixed effects which may be attributed to the used FDI as a dependent variable. However, the study suggests that FDI in manufacturing sector significantly and positively impact economic growth in the host economies. On the other hand, Wang (2009) also notes that FDI inflows in non-manufacturing areas fail to play a main role in improving the growth of the economy. In a similar study, Awan, M. Z, et al., (2011) examines the FDI impact on Pakistani economy using time series data for the period 1971-2006. The results reveal that determinant variables like degree of trade openness, gross fixed capital formation and inflation rate are statistically significant with positive signs while account balance had a negative sign.

In Yemen, AL-Shebami, et al. (2013) employs secondary data to examine the macroeconomic factors determining inflows of FDI from 1991 to 2008. These factors are categorized into five groups, including market size, cost-related factors, infrastructure, openness of trade, and human capital. Using the Autoregressive Distributed Lag (ARDL) approach, the empirical results suggests that in the long run, the most dominant factor determining FDI in Yemen is the infrastructure. This is followed by exchange rate, while other factors such as real gross domestic product per capita, trade openness, and human capital have less influence on FDI inflow. However, interest rate and the growth of real gross domestic product are found to be insignificant in influencing the FDI inflow in the long-run. On the other hand, their results also indicate that in the short run, real gross domestic product per capita, trade openness, and infrastructure have positive impacts on the FDI while the exchange rate and human capital affect FDI inflow negatively. Also in the short run, the growth of real gross domestic product and interest rate are found to be insignificant in influencing FDI.

\subsection{Grass Domestic Product Growth Rate}

The Grass domestic product growth rate is a significant factor considered by foreign investor while taking a decision for investment in any country. Thus, researchers have tried to study different related aspects of Grass Demostic Product growth rate and FDI inflows in their researches. A research conducted by Martinez-Zarzoso (2013) explains that higher domestic economic growth specify a high production rate along with a rise in investors' confidence to invest. Moreover, Martinez-Zarzoso \& Nowak-Lehmann (2003) put forward that domestic rise in the economy usually encourage the investors from other countries to trust the host country for their business. The national economic development is termed as the GDP growth rate, which is the measure of economic performance of a country. This can be seen by the production rate, consumption, diversity and quality of goods along with various other economic facilities given in the country.

Mainly, macroeconomic factors tend to impact on the FDI inflow into a country. According to Gross \& Trevino (1996), countries that have high levels of growth rate of GDP greatly tend to increase the inflow of FDI by winning the confidence of the Multinational Companies (MNCs) and encouraging them to invest specially when a steady development is recorded in the growth. However, better development in economy attracts the investors and they believe it a potential market for big profit on investments comes with higher FDI inflow (Biglaiser \& DeRouen, 2011). By using panel data on 52 middle income countries for the period 1984-2012, Mina, W. (2014), found that there is the effect of GDP on FDI in addition to other factors. In india the study by Pradhan, A. K., \& Kelkar, S. (2014), by using time series data over the period 1991 to 2012, indicated positive relationship between GDP and FDI. In North African countries, such as Egypt, the study by Badr, O. M., \& Ayed, T. L. (2015), for the 
period 1961-2012, found that FDI is explained by GDP. In the context of Yemen, AL-Shebami, A., et al. (2013), found a negative correlation was revealed between Real Gross Domestic Product per Capita and FDI inflow for the period from 1991-2008. On the basis of above mentioned argument the following proposition is drawn for further examination.

\section{H1. GDP growth rate have an impact on FDI inflow.}

\subsection{Exchange Rate}

The exchange rate is one of the most significant issues tackled in economic research (Brixiova et al., 2014; Pan \& Song, 2014; Bilawal et al., 2014; Lily et al., 2014; Goldberg, 2009). It has been acknowledged that there is an association between FDI and exchange rate. If the currency of a country is devalued, there is a chance for foreign investors to invest in that country to buy assets at lower prices. This is especially seen in the case of foreign firms having identified specific potentiality in their targeted markets envisaged (Blonigen \& Ma, 2011). Some previous studies (Nurudeen, Auta, \& Wafure, 2011; Ali, Khrawish, \& Siam, 2010; Adam \& Tweneboah, 2009; Osinubi \& Amaghionyeodiwe, 2009; Dumludag, 2009; Kaya \& Yilmaz, 2003) have reported positive impact of exchange rate on FDI inflows.

The outcome of the exchange rate of FDI inflows has been documented in the literature. For example, studies

(Clare \& Gang, 2010; Kiyota \& Urata, 2008; Jenkins \& Thomas, 2002; Erdal \& Tatoglu, 2002; Love \& Lage-Hidalgo, 2000; Mowatt \& Zulu, 1999; Blonigen, 1997; Froot \& Stein, 1991) have found that the exchange rate can lead to fluctuation of FDI by affecting the cost of acquiring foreign exchange. This is because a decrease in domestic currency value against foreign currency value or depreciation of domestic exchange rate will make it less expensive for a foreign investor to invest in the developing economy. Thus, depreciation of the exchange rate of a country will stimulate the inflows of FDI. Based on the current literature, the following hypothesis are stated for investigation.

\section{H2. Exchange Rate has an impact on FDI inflows.}

\subsection{Inflation Rate}

Inflation rate is considered a vital factor in a country's economic development. Rate of inflation is considered as an important element that affects the FDI inflows. The rate of inflation brings the overall financial performance of host nations to light (Hailu, 2010). Furthermore, high inflation represents the failure of the government of that country in handling its budget, and this depicts that the central bank is failed to accomplish effective monetary policy (Schneider \& Frey, 1985). Generally, higher inflation rate is linked with the lower FDI inflows. Akinboade et al. (2006) draw the conclusion that the high inflation rate signifies instability in the country. Some studies such as (Bissoon, 2012; Parajuli \& Kennedy, 2010; Hailu, 2010; Kok \& Ersoy, 2009; Bouoiyour, 2007; Haile \&Assefa, 2006; Nunes, Oscategui, \& Peschiera, 2006; Asiedu, 2006; Obwona, 2001) reveal that high inflation will hinder FDI inflows. Furthermore, a positive relationship was found between inflation and FDI (Azam \& Lukman, 2010; Ali, Khrawish, \& Siam, 2010). In contrast, several studies (Shahzad \& Al-Swidi, 2013; Anyanwu, 2012; Nurudeen, Auta, \& Wafure, 2011; Parajuli \& Kennedy, 2010; Vijayakumar et al., 2010; Onyeiwu, 2003; Obwona, 2001) have found that the relationship between inflation and FDI is not significant. The foregoing leads to the following hypothesis.

\section{H3. The stable Inflation Rate has significant impact on FDI inflows.}

\subsection{Gross National Income}

The Gross national income (GNI) is the total amount of output produced by the domestic and foreign residents of a country. This includes gross domestic product (GDP) plus net income from abroad, calculated as factor incomes earned by foreign residents minus income earned by the non-residents in the domestic economy (Todaro \& Smith, 2011). The ability of a country to sustain high growth rates in GNI determines its economic development and competitiveness. In such country, the purchasing power of the citizen increases and thus influences the FDI flows. De Mello (1999) reported that FDI has positive and significant influence on the economic growth of a country whose level of income is high. However, Antwi et al., (2013) found the association of GNI and FDI to be negative. GNI consider the following hypothesis to test with FDI.

\section{H4. GNI has an Impact on FDI inflows.}

\subsection{Balance of Payment}

The evidences presented in this research study show that FDI inflows have the tendency to make the position of host country better regarding the balance of payment. By taking into the consideration the data of 72 developing countries from 1970 to 2008, Majeed and Eatazaz (2009) reveal the features of the host countries that are 
essential in the decision making process with reference to the location of Multinational companies (MNs) in progressing countries. Various researches like (Chaudhary et al., 2009; Toda \& Yamamoto, 1995) have demonstrated that FDI, one of the determinants (employed labor force, human capital index, domestic savings, and the balance of payments) ensures speedy development in economy. Furthermore, Results obtained from the research point out that the balance of payment and inflation has significant influence on FDI inflows but negative. In Pakistan, study by Shahzad, A., \& Al-Swidi, A. K. (2013) by using the authentic annual data for the period 1991 to 2011 tends Balance of Payment to be a significant determinant of FDI inflows when the Political stability as moderating effect . Based on above mentioned discussion, the following hypothesis is deduced.

\section{H5. Sufficient Balance of Payment (BOP) has an impact on FDI inflows.}

\section{PS and FDI Inflows}

The PS has a significant impact on macroeconomic balance and in the making favorable environment for business in a country. Mainly, political risks rely on PS and good governance (Shahzad et al., 2012; Husain, 2009). Latest research carried out by Shahzad et al. (2012) accounts that political stability encourages forcing greater inflows of FDI in the developing countries. On the other hand, Yemen has been facing an unending political instability. Thus, this has badly affected the foreign and domestic investment and offer limited investment options. In this context, the country's economic development and growth process are negatively impacted by its unfavorable features on the physical and human resources. In case of political instability experienced by a country, foreign investors do not tend to start any projects except when they are confident of a favorable environment that is encouraging for investment (World Bank, 2011; UNCTAD, 2010; Brada et al., 2005).

Certainly, the decision process of foreign investments could be adversely influenced by the determinants of political risks like regime change, economic intervention by government, legislation of property rights, and the red tape (Frey \& Schneider, 1985). On the other hand, the FDI decision process is extremely valuable for the foreign investors and organizations to know the status of the governance index with reference to transparency of the administration processes; reduction in corruption; and peaceful environment (World Bank, 2006). Meanwhile, Clare and Gang (2010) employed a cross-sectional time series panel comprising of 53 developed and developing nations over the period 1999-2003. They noted that political stability positively influenced FDI, but a significant influence was limited to developing countries. This indicated higher concern for political risk in the developing countries compared to their developed counterparts. Additionally, Obwona (2001) showed that foreign investors considered the political situation in Uganda because of the fact that a stable political environment is important to their investment confidence.

A more extensive study was conducted by Qian and Baek (2011) to examine whether or not political risks hinder FDI in 116 countries from 1984 to 2008. They showed that political risk significantly determined FDI in both categories of nations. A fixed effect model and a dynamic panel model were utilized by Krifa-Shneider and Matei (2010) to examine the 33 developing and transition nations from 1996-2008. They reported a negative association between political risk levels and FDI inflow. This negative association between political risk and FDI inflows was supported by Acheampong, P., \& Osei, V. (2014); Burger, M., et al., (2013); Solomon \&Ruiz (2012); Kim, H. (2010); and Asiedu (2006) and despite the argument that political risk could minimize FDI inflow, some authors have shown that political risks play a key role in the decision of the firm to invest abroad (Esew \& Yaroson, 2014; Samimi \& Rezanejad, 2013; Bitzenis, 2007; Block, 2000; Levis, 1979; Brewer, 1983). For example, Li and Resnick (2003) fail to show a significant impact of political instability on the FDI inflows. Similarly, Levis (1979) also reveals that political variables takes second place to economic ones when it comes to FDI inflows determination. A similar finding highlighted by Brewer (1983) indicated a very weak correlation between government instability and FDI. Other studies (Asiedu, 2002; Olibe \& Crumbley, 1997) also fail to show a statistical association between FDI and political instability. This result is found in the context of developed countries (Jimenez et al., 2011; Bitzenis et al., 2009). According to Shahzad, A., \& Kaid Al-Swidi, A. (2013), macroeconomic determinant impact by political stability. Therefore, the following hypotheses are formulated as thus:

H6: PS moderates the impact between GDP growth rate and the FDI inflows.

H7: PS moderates the impact between Exchange Rate and the FDI inflows in Yemen

H8: PS moderates the impact between Inflation Rate and the FDI inflows in Yemen

H9: PS moderates the impact between GNI and the FDI inflows in Yemen.

H10: P S moderates the impact between Balance of Payment and the FDI inflows in Yemen. 


\section{Research Framework}

The research framework in Figure 2 is devised to trace the impact of selected macroeconomic and business environment variables on FDI in Yemen during the period 1990 to 2013.

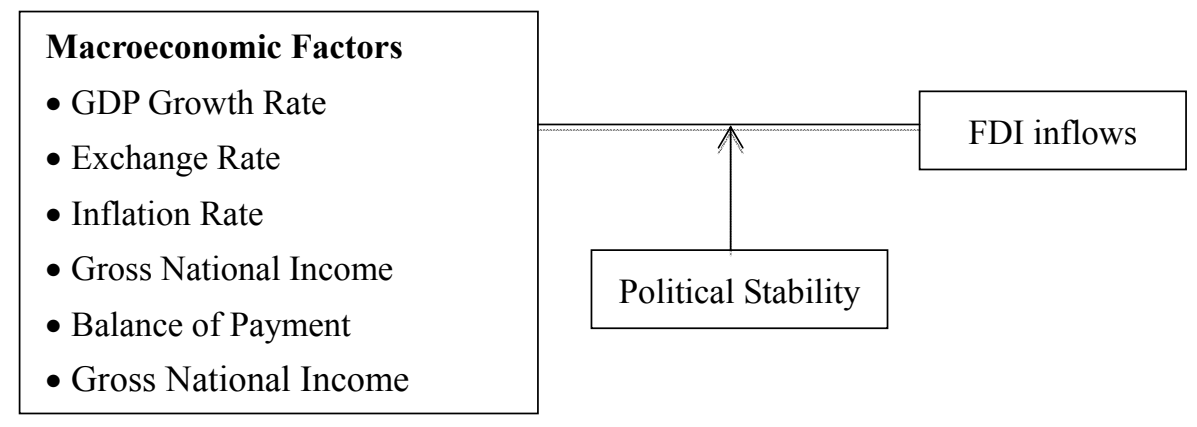

Figure 2. Research framework

The expected relationships of the macroeconomic variables with the FDI inflows and the expected level of the moderating variable, political stability are as stated earlier in the highlighted hypotheses.

\section{Data Analysis and Results}

Foreign direct investment inflows (FDI inflows) and gross domestic production growth rate (GDPGR) are on an annual basis and are the data is recorded from the World Bank Indicator reports. The exchange rate is considered as the rate of a nation's currency with respect to some other currency and the inflation rate corresponds to the consumer price index change in years. Gross National Income is the sum of domestic and foreign output, income owned by people of the host country, containing gross domestic product (GDP) in addition to the incomes earned by foreign residents, minus income earned in the domestic economy by non-residents. The balance of payment finds out the external balance or foreign trade position of the country. At the end, the political stability index (PSI). The data for these variables gather from the Indicator reports provided by the World Bank. In order to study the effects of these macroeconomic variables with the moderating role of PS on the FDI inflows in Yemen as mentioned during drawing the hypotheses and demonstrated in the research plan, the current study adopt the steps as follow.

\subsection{Units Root Tests (ADF Test)}

Spurious regression can be avoided if characteristics of time series data are analyzed at the start to know the nature of variables. These variables can either be stationary or non-stationary. Augmented Dickey Fuller (ADF) method is used in this study. Data showed in table, the dependent variable of FDI inflows and the variety of macroeconomic variables like, Gross domestic product growth rate, Exchange Rate, Inflation rate, Balance of Payment, Gross National Income, and FDI and PS are stationary.

Table 2. ADF unit root test results using the trend and intercept

\begin{tabular}{lllll}
\hline & Variable & 1st Diff & 2nd Diff & Lagged \\
\hline 1 & FDI & 0 & $\mathrm{~S}$ & 2 \\
2 & GDPGR & $\mathrm{S}$ & 0 & 1 \\
3 & Exchange Rate & 0 & $\mathrm{~S}$ & 1 \\
6 & Inflation rate & $\mathrm{S}$ & 0 & 1 \\
7 & GNI & 0 & $\mathrm{~S}$ & 1 \\
8 & BOP & $\mathrm{S}$ & 0 & 1 \\
9 & PSI & 0 & $\mathrm{~S}$ & 1 \\
\hline
\end{tabular}

\subsection{Standard Regression Analysis of FDI Inflows}

Having satisfied the regression assumptions, the FDI model is estimated to examine its significant predictors (GDPGR, Exchange Rate, Inflation Rate, GNI and BOP). From the results in Table 3, only GDPGR has significant negative $(\beta=-.470, \mathrm{t}=-2.312, \mathrm{p}<0.05)$ impact of the FDI inflows at the $5 \%$ level. This result, 
however, supports the hypothesis H1. The exchange rate, inflation rate, balance of payment, gross national income are not significant factors of the FDI inflows in the state of Yemen, These results, however, fail to support the hypothesis $\mathrm{H} 2, \mathrm{H} 3, \mathrm{H} 4$, and $\mathrm{H} 5$.

Table 3. Estimated results of the FDI inflows

\begin{tabular}{lll}
\hline Variables & Beta & T-value \\
\hline GDPGR & $-.470^{* *}$ & -2.312 \\
Exchange Rate & -.334 & -.770 \\
INFRATE & .162 & .661 \\
GNI & .530 & 1.217 \\
BOP & -.223 & -.927 \\
F value & & 1.906 \\
F Sig. & & .134 \\
$\mathrm{R}^{2}$ & & 0.346 \\
Adjusted $\mathrm{R}^{2}$ & & 0.165 \\
Durbin Watson & & 2.568 \\
\hline
\end{tabular}

\subsection{Multiple Analysis of Moderating Effect}

In the above mentioned model, the interaction terms lie among the macroeconomic variables, business environment variables and political stability are investigated to verify the moderating influence. The hierarchical regression outcomes are declared in steps. Foremost, the moderating influence of Political stability was examined on the already discussed relations following Frazier, Tix, \& Barron (2004). Findings shown in Table 4, the exchange rate, rate of inflation and gross national income describe them as significant impact of the FDI inflows at the 0.01 level of significance whilst the balance of payment is significant at the $5 \%$ level.

Table 4. Results of the moderating effect of PS

\begin{tabular}{lllllll}
\hline Variables & Predictors & T value & Moderated & T value & Interactions & T value \\
\hline GDPGR & $-.470^{* *}$ & -2.312 & $-.328^{*}$ & -1.881 & $-.547^{* *}$ & -2.338 \\
Exchange Rate & -.334 & -.770 & $-.799^{*}$ & -2.052 & .823 & 1.134 \\
INFRATE & .162 & .661 & .021 & .100 & $1.162^{* *}$ & 2.816 \\
GNI & .530 & 1.217 & $2.024^{* * *}$ & 3.340 & $1.181^{*}$ & 2.068 \\
BOP & -.223 & -.927 & -.342 & -1.690 & $-.691^{* *}$ & -2.637 \\
PSI & & & $1.346^{* *}$ & 3.063 & $1.911^{* *}$ & 2.808 \\
GDPGR_PSI & & & & .171 & .914 \\
Exchange Rate_PSI & & & & & $-2.853^{* *}$ & -2.810 \\
INFRATE_PSI & & & & $-1.557^{* * *}$ & -3.385 \\
GNI_PSI & & & & $2.100^{* * *}$ & 3.204 \\
BOP_PSI & & & & $.661^{* *}$ & 2.446 \\
F value & & & 3.891 & & 4.724 \\
F Sig. & .1406 & & .013 & & .006 \\
$\mathrm{R}^{2}$ & .346 & & .579 & & 0.812 \\
Adjusted R ${ }^{2}$ & & 0.165 & & 0.430 & & 0.640 \\
$\mathrm{R}^{2}$ change & 0.346 & & 0.233 & & 0.234 \\
Significant F change & & .143 & & 0.007 & & 0.056 \\
$* * *: \mathrm{p}<0.01 ; * *: \mathrm{p}<0.05 ; *: P<0.1$ & & & & & \\
\hline
\end{tabular}

Outcomes shown in Table 4 depict the interaction terms among political stability and macroeconomic variables. Though, the interaction term lies among exchange rate $(\beta=-2.853, \mathrm{t}=-2.810, \mathrm{p}<0.05)$, and inflation rate $(\beta=$ $-1.557, \mathrm{t}=-3.385, \mathrm{p}<0.01)$ is negative significant at the 0.05 level, and 0.01 respectively, and the interaction term in case gross national income is $(\beta=2.100, \mathrm{t}=3.204, \mathrm{p}<0.01)$, and in case of the balance of payment is $(\beta=.661$, 
$\mathrm{t}=2.446, \mathrm{p}<0.05)$ is positive significant at the 0.01 level, and 0.05 respectively. These findings describe that political stability as significant moderator that influence exchange rate, inflation rate, gross national income, and balance of payment on FDI inflows. Nevertheless, these findings are in line with the hypothesis H7, H8, H9 and H10.

\section{Discussions, Conclusion and Recommendations}

This study's results are based on the analysis of FDI inflows in Yemen for the past two decades. In order to investigate the propositions of the study, hierarchical multiple linear regression was used. The findings obtained indicate that all the hypotheses are rejected except only one. Specifically, out of the stated hypothesis H1, H2, $\mathrm{H} 3, \mathrm{H} 4$ and $\mathrm{H} 5$, only $\mathrm{H} 1$ is supported with FDI inflows in Yemen. In investigating the effects of moderating variable, PS on the macroeconomic variables and FDI inflows, the results support the hypothesis H7, H8, H9 and H10. The results suggest that the political stability plays a significant role among other determinants of foreign investment in Yemen. In addition, exchange rate and gross national income nexus are influenced by the level of political system stability in the country.

A good indicator for any economy is a consistent growth of GDP because it motivates foreign investment in the host country. The GDP growth rate is an important factor determining the FDI. Therefore, Yemeni policy makers should promote the enhancement of GDP grow rate for the FDI inflow into the country. In addition, it is necessary for Yemen to provide the attractive packages which could motivate the investment of high tech companies in the county. The policy makers in Yemen should draw on the experience of the GCC countries and other neighboring countries. Favorable balance of payment of the host country also motives foreign investment in the country. This study paid attention to and stated the role of political stability as a moderating variable for macroeconomic stability. Therefore, a country with political stability, favorable balance of payments and growth in GNI will have its economic growth improved. However, political stability in Yemen has been ranked to be low compared to other developing countries like Saudi Arabia, Oman, and Djibouti. Therefore, the Yemeni policy makers should make a rule of law which would protect the foreign investment and strive to pursue a policy that will guarantee a stable political system.

To this extent, the present study investigates the parameters influencing the inflows of foreign direct investment in Yemen over the period 1990 to 2013. It could be suggested that the policy-makers of Yemen should rehash the FDI policy which would stimulate more investment into the country in order to address the declining trend in the FDI inflow. Selective FDI policies could be made to channel FDI inflows into the country by including a set of positive and negative lists of action. Positive list in this sense implies some sectors where FDI should be encouraged and promoted while the negative list refers to some sectors where FDI inflows should be discouraged or disallowed, for example, defines good and the service sector. The adequate decision should be made on the approval procedure and screening mechanism to achieve the objective of FDI policy. Indeed, it is necessary for a developing country like Yemen to design a well-planned FDI policy that could greatly enhance the country's economic growth with stable macroeconomic goals. Such policy should be flexible for the practical determination of FDI inflows in the future.

With respect to future researches, one of the key suggestions are to examine in-depth the moderating effect of the economic stability between various determinants and the other variable related to business with FDI inflows.

\section{References}

Acheampong, P., \& Osei, V. (2014). Foreign Direct Investment (FDI) Inflows into Ghana: Should the Focus Be on Infrastructure or Natural Resources? Short-Run and Long -Run Analyses. International Journal of Financial Research, 5(1). http://dx.doi.org/10.5430/ijfr.v5n1p42

Adam, A. M., \& Tweneboah, G. (2009). Foreign Direct Investment and Stock market Development: Ghana's Evidence. International Research Journal of Finance and Economics, 26, 178-185.

Akcay, S. (2001). Is Corruption an Obstacle for Foreign Investors in Developing Countries? Cross Country Evidence. Yapi Kredi Economic Review, 12(2), 27-34.

Akinboade, O. A., Siebrits, F. K., \& Roussot, E. N. (2006). Foreign Direct Investment in South Africa.

Alfaro, L., Chanda, A., Kalemli-Ozcan, S., \& Sayek, S. (2004). FDI and Economic Growth: The Role of Local Financial Markets. Journal of International Economics, 64(1), 89-112. http://dx.doi.org/10.1016/S0022 -1996(03)00081-3

Ali, Khrawish, H., \& Siam, W. Z. (2010). Determinants of Direct Foreign Investment: Evidence from Jordan. Business and Economic Horizons, 1, 67-75. http://dx.doi.org/10.15208/beh.2010.10

Almounsor, A. (2010). Inflation Dynamics in Yemen: An Empirical Analysis. IMF Working Papers, 10(144), 1. 
http://dx.doi.org/10.5089/9781455201273.001

AL-Shebami, A., Almsafr, M., \& Shaari, M. (2013). A Bounds Testing Approach to Co-integration: Determinants of Foreign Direct Investments Inflows to Yemen. Journal of Advanced Social Research, 3(7).

Antwi, S., Mills, E. F. E. A., Mills, G. A., \& Xicang, Z. H. A. O. (2013). Impact of Foreign Direct Investment on Economic Growth: Empirical Evidence from Ghana. International Journal of Academic Research in Accounting, Finance \& Management Sciences, 3(1), 18-25.

Anyanwu, J. C. (2012). Why does Foreign Direct Investment Go where it Goes? New Evidence From African Countries. Annals of Economics and Finance, 13(2), 433-470.

Asiedu, E. (2006). Foreign Direct Investment in Africa: The Role of Natural Resources, Market Size, Government Policy, Institutions and Political Instability. World Economy, 29(1), 63-77. http://dx.doi.org/10. 1111/j.1467-9701.2006.00758.x

Ataullah, A., Cockerill, T., \& Le, H. (2004). Financial Liberalization and Bank Efficiency: A comparative Analysis of India and Pakistan. Applied Economics, 36(17), 1915-1924. http://dx.doi.org/10.1080/000368 404200068638

Awan, M. Z., Khan, B., \& uz Zaman, K. (2011). Economic Determinants of Foreign Direct Investment (FDI) in commodity producing sector: A case Study of Pakistan. African Journal of Business Management, 5(2), 537-545.

Awan, M. Z., uz Zaman, K., \& Khan, B. (2010). Determinants of Foreign Direct Investment in Services Sector of Pakistan: An Econometric Approach. Global Financial Crisis: Causes, Emerging Trends and Strategy, 5(2), 167.

Azam, M., \& Lukman, L. (2010). Determinants of Foreign Direct Investment in India, Indonesia and Pakistan: A quantitative Approach. Journal of Managerial Sciences, 4(1), 31-44.

Badr, O. M., \& Ayed, T. L. (2015). The Mediator Role of FDI in North Africa: Case of Egypt. Journal of Advanced Management Science, 1-7. http://dx.doi.org/10.12720/joams.3.1.1-7

Biglaiser, G., \& DeRouen, K. (2011). How Soon is Now? The Effects of the IMF on Economic Reforms in Latin America. The Review of International Organizations, 6(2), 189-213. http://dx.doi.org/10.1007/s11558011-9123-8

Bilawal, M., Ibrahim, M., Abbas, A., Shuaib, M., Ahmed, M., Hussain, I., \& Fatima, T. (2014). Impact of Exchange Rate on Foreign Direct Investment in Pakistan. Advances in Economics and Business 2(6), 223-231.

Bissoon, O. (2012). Can Better Institutions Attract More Foreign Direct Investment? Evidence from Developing Countries. International Research Journal of Finance and Economics, 82, 142-158.

Bitzenis, A. (2006). Decisive FDI Barriers that Affect Multinationals' Business in A transition Country. Global Business and Economics Review, 8(1), 87-118.

Bitzenis, A., Tsitourasb, A., \& Vlachosa, V. A. (2009). Decisive FDI Obstacles as an Explanatory Reason for limited FDI Inflows in an EMU Member State: The Case of Greece. The Journal of Socio-Economics, 38, 691-704. http://dx.doi.org/10.1016/j.socec.2009.03.001

Block, S. (2000). Integrating Traditional Capital Budgeting Concepts into an International Decision-Making Environment. The Engineering Economist, 45(4), 309-325. http://dx.doi.org/10.1080/00137910008967555

Blonigen, B. A. (1997). Firm-Specific Assets and the Link between Exchange Rates and Foreign Direct Investment. The American Economic Review, 447-465.

Blonigen, B., \& Ma, A. C. (2011). China's Growing Role in World Trade: Please Pass the Catch-Up: The Relative Performance of Chinese and Foreign Firms in Chinese Exports.

Bouoiyour, J. (2007). The Determining Factors of Foreign Direct Investment in Morocco. Saving and Development, 31(1), 91-106.

Brada, J. C., Kutan, A. M., \& Yigit, T. M. (2005). The Effects of Transition and Political Instability on Foreign Direct Investment in ECE Emerging Market. Paper Presented at the United Nations Economic Commission for Europe (UNECE) Spring Seminar.

Brewer, T. L. (1983). The Instability of Governments and the Instability of Controls on Funds Transfers by Multinational Enterprises: Implications for Political Risk Analysis. Journal of International Business Studies, 14(3), 147-157. http://dx.doi.org/10.1057/palgrave.jibs.8490534

Brixiova, Z., Egert, B., \& Essid, T. H. A. (2014). The Real Exchange Rate and External Competitiveness in 
Egypt, Morocco and Tunisia. Review of Middle East Economics and Finance, 10(1), 25-51. http://dx.doi. org/10.1515/rmeef-2013-0014

Brooks, D. H., Fan, E. X., Sumulong, L. R., \& Bank, A. D. (2003). Foreign Direct Investment in Developing Asia: Trends, Effects, and Likely Issues for the Forthcoming WTO Negotiations. Asian Development Bank.

Burger, M., Ianchovichina, E., \& Rijkers, B. (2013). Risky Business: Political Instability and Greenfield Foreign Direct Investment in the Arab World. Policy Research Working Papers. http://dx.doi.org/10.1596/1813-9450 $-6716$

Central Bank of Yemen (CBY). (2008). Annual Report 2008. Yemen. Retrieved from http://www.centralbank.gov.ye/App_Upload/annl_rep2008_en.pdf

Central Bank of Yemen (CBY). (2010). Annual Report 2010. Yemen. Retrieved from http://www.centralbank.gov.ye/App_Upload/annl_rep2010_en.pdf

Chaudhary, A. R., Iqbal, A., \& Gillani, S. Y. M. (2009). The Nexus between Higher Education and Economic Growth: An Empirical Investigation for Pakistan. Pakistan Journal of Commerce and Social Sciences, 3, $1-9$.

Cheung, Y. W., \& Qian, X. (2009). Hoarding of International Reserves: Mrs Machlup's Wardrobe and the Joneses. Review of International Economics, 17(4), 824-843. http://dx.doi.org/10.1111/j.1467-9396.2009.00850.x

Cho, J. W. (2004). Foreign Direct Investment: Determinants, Trends inflows and Promotion Policies. Investment Promotion and Enterprise Development Bulletin for Asia and the Pacific, 1, 99-112.

Chowdhury, A., \& Mavrotas, G. (2006). FDI and Growth: What Causes What? World Economy, 29(1), 9-19. http://dx.doi.org/10.1111/j.1467-9701.2006.00755.x

Clare, G., \& Gang, I. N. (2010). Exchange Rate and Political Risks, Again. Emerging Markets Finance and Trade, 46(3), 46-58. http://dx.doi.org/10.2753/REE1540-496X460303

Crespo, N., \& Fontoura, M. P. (2007). Determinant Factors of FDI Spillovers-What Do We Really Know? World Development, 35(3), 410-425. http://dx.doi.org/10.1016/j.worlddev.2006.04.001

De Mello, L. (1999). Foreign Direct Investment-led Growth: Evidence from Time Series and Panel Data. Oxford Economic Papers, 51(1), 133-151. http://dx.doi.org/10.1093/oep/51.1.133

Deichmann, J., Karidis, S., \& Sayek, S. (2003). Foreign Direct Investment in Turkey: Regional Determinants. Applied Economics, 35(16), 1767-1778. http://dx.doi.org/10.1080/0003684032000126780

Duce, M. (2003). Definitions of Foreign Direct Investment (FDI): A Methodological Note. Paper for the Committee on the Global Financial System Working Group, Banco Deespana, Madrid.

Dumludag, D. (2009). An Analysis of the Determinants of Foreign Direct Investment in Turkey: The Role of the Institutional Context. Journal of Business Economics and Management, 10(1), 15-30. http://dx.doi.org/10. 3846/1611-1699.2009.10.15-30

Dunning, J. H. (1988). The Eclectic Paradigm of International Production: A Restatement and Some Possible Extensions. Journal of International Business Studies, 19(1), 1-31. http://dx.doi.org/10.1057/palgrave. jibs. 8490372

Erdal, F., \& Tatoglu, E. (2002). Locational Determinants of Foreign Direct Investment in an Emerging Market Economy: Evidence From Tukey. Multinational Business Review, 10, 21-27.

Esew, N. G., \& Yaroson, E. (2014). Institutional Quality and Foreign Direct Investment (FDI) In Nigeria: A Prognosis. IOSR Journal of Humanities and Social Science, 19(6), 37-45. http://dx.doi.org/10.9790/083719653745

Froot, K. A., \& Stein, J. C. (1991). Exchange Rates and Foreign Direct Investment: An Imperfect Capital Markets Approach. The Quarterly Journal of Economics, 106(4), 1191-1217. http://dx.doi.org/10.2307 $/ 2937961$

Goldberg, L. S. (2009). Exchange Rates and Foreign Direct Investment. The Princeton Encyclopedia of the World Economy, 1, 393-396.

Gorg, H. (2004). Much Ado about Nothing? Do Domestic Firms Really Benefit from Foreign Direct Investment? The World Bank Research Observer, 19(2), 171-197. http://dx.doi.org/10.1093/wbro/lkh019

Grosse, R., \& Trevino, L. J. (1996). Foreign Direct Investment in the United States: An Analysis by Country of Origin. Journal of International Business Studies, 27(1), 139-155. http://dx.doi.org/10.1057/palgrave.jibs. 8490129

Habib, M., \& Zurawicki, L. (2002). Corruption and Foreign Direct Investment. Journal of International Business 
Studies, 33(2), 291-307. http://dx.doi.org/10.1057/palgrave.jibs.8491017

Haile, G. A., \& Assefa, H. (2006). Determinants of Foreign Direct Investment in Ethiopia: A time-series analysis.

Hailu, Z. A. (2010). Demand Side Factors Affecting the Inflow of Foreign Direct Investment to African Countries: Does Capital Market Matter? International Journal of Business and Management, 5(5), 104-116. http://dx.doi.org/10.5539/ijbm.v5n5p104

Hela, B. (2014). Knowledge Economy, Governance and FDI: Case of Tunisia. Journal of Business Management and Economics, 5(2), 52-62.

Husain, I. (2009). The Role of Politics in Pakistan's Economy. Journal of International Affairs, 63(1), 1-18.

Javed, K., Falak, S., Awan, R., \& Ashfaq, M. (2012). Foreign Direct Investment, Trade and Economic Growth: A Comparison of Selected South Asian Countries. International Journal of Humanities and Social Science, 2(5).

Jenkins, C., \& Thomas, L. (2002). Foreign Direct Investment in Southern Africa: Determinants, Characteristics and Implications for Economic Growth and Poverty Alleviation. CSAE, Univ. of Oxford.

Jimenez, A., de la Fuente, J. M., \& Duran, J. J. (2011). Is there an East-West Structure in the Location of FDI in Europe? the Role of Institutions and Political Risk. Research in Economics and Business: Central and Eastern Europe, 3, 5-23.

Kaya, \& Yılmaz (2003). Turkiye'de Dogrudan Yatırımların Belirleyicileri: 1970-2000. AtatUrk Universitesi BF Dergisi, 17(3-4), 39-56.

Kim, H. (2010). Political Stability and Foreign Direct Investment. IJEF, 2(3), 59. http://dx.doi.org/10.5539/ijef. v2n3p59

Kiyota, K., \& Urata, S. (2008). The Role of Multinational Firms in International Trade: The Case of Japan. Japan and the World Economy, 20(3), 338-352. http://dx.doi.org/10.1016/j.japwor.2007.03.003

Kobrin, S. J. (2005). The Determinants of Liberalization of FDI Policy in Developing Countries: A cross-Sectional Analysis, 1992-2001. Transnational Corporations, 14(1), 67-104.

Kok, R., \& Ersoy, A. B. (2009). Analyses of FDI Determinants in Developing Countries. International Journal of Social Economics, 36(1/2), 105-123. http://dx.doi.org/10.1108/03068290910921226

Krifa-Schneider, H., \& Matei, I. (2010). Business Climate, Political Risk and FDI in Developing Countries: Evidence from Panel Data. International Journal of Economics and Finance, 2(5), 54-65. http://dx.doi.org/ 10.5539/ijef.v2n5p54

Kumar, N., \& Chadha, A. (2009). India's Outward Foreign Direct Investments in Steel Industry in a Chinese Comparative Perspective. Industrial and Corporate Change, 18(2), 249-267. http://dx.doi.org/10.1093/icc/ dtp004

Levis, M. (1979). Does Political Instability in Developing Countries Affect Foreign Investment Flow: An Empirical Examination. Management International Review (MIR), 19(3), 59-69.

Li, Q., \& Resnick, A. (2003). Reversal of Fortunes: Democratic Institutions and Foreign Direct Investment Inflows to Developing Countries. Int. Org., 57(1), 175-211. http://dx.doi.org/10.1017/S0020818303571077

Lily, J., Kogid, M., Mulok, D., Thien Sang, L., \& Asid, R. (2014). Exchange Rate Movement and Foreign Direct Investment in Asean Economies. Economics Research International, 1-10. http://dx.doi.org/10.1155/2014/ 320949

Love, J. H., \& Lage-Hidalgo, F. (2000). Analysing the Determinants of US Direct Investment in Mexico. Applied Economics, 32(10), 1259-1267. http://dx.doi.org/10.1080/000368400404416

Madani, S., \& Nobakht, M. (2014). Political Regimes and FDI Inflows: Empirical Evidence from Upper Middle Income Countries. Journal of Finance and Economics, 2(3), 75-82. http://dx.doi.org/10.12691/jfe-2-3-4

Mahdi, O. R., Almsafir, M. K., \& Yao, L. (2011). The Role of Knowledge and Knowledge Management in Sustaining Competitive Advantage within Organizations: A review. African Journal of Business Management, 5(23), 9912-9931.

Majeed, M. T., \& Ahmad, E. (2009). An Analysis of Host Country Characteristics that Determine FDI in Developing Countries: Recent Panel Data Evidence. The Lahore Journal of Economics, 14(2), 71-96.

MartÃnez-Zarzoso, I., \& Nowak-Lehmann, F. (2003). Augmented Gravity Model: An Empirical Application to Mercosur-European Union Trade Flows. Journal of Applied Economics, 6(2), 291-316.

Martínez-Zarzoso, I. (2013). The Log of Gravity Revisited. Applied Economics, 45(3), 311-327. http://dx.doi.org $/ 10.1080 / 00036846.2011 .599786$ 
Mhlanga, N., Blalock, G., \& Christy, R. (2010). Understanding Foreign Direct Investment in the Southern African Development Community: An Analysis based on Project-level Data. Agricultural Economics, 41(3-4), 337-347. http://dx.doi.org/10.1111/j.1574-0862.2010.00440.x

Mina, W. (2014). But Most of All We Love Each Other: Does Social Cohesion Pay off? Evidence from FDI Flows to Middle Income Countries International Center for Public Policy, Working Paper Series, 8.

Mowatt, R., \& Zulu, T. (1999). Intra-Regional Private Capital Flows in Eastern and Southern Africa: A study of South African investment in the Region. ACREFSA/FDI workshop on Intra-Regional Private Capital Flows in Eastern and Southern Africa, Harare.

Musibah, A. S., Arfan, S., \& Faudziah, H. B. F. (2014). The Role of Foreign Investment Inflow in the Yemen's Economy Growth. In Comparison with the MENA Countries, International Congress on Economy, Finance and Business (ICEFB, 2014). Nagoya, JAPAN.

Nunes, L. C., Oscategui, J., \& Peschiera, J. (2006). Determinants of FDI in Latin America: Document De Trabajo, 252, 1-12.

Nurudeen, A., Auta, E. M., \& Wafure, O. G. (2011). Determinants of Foreign Direct Investment in Nigeria: An Empirical Analysis. Global Journal of Human Social Science, 10(1), 26-34.

Obwona, M. B. (2001). Determinants of FDI and their Impact on Economic Growth in Uganda. African Development Review, 13(1), 46-81. http://dx.doi.org/10.1111/1467-8268.00030

Olibe, K. O., \& Crumbley, C. L. (1997). Determinants of US Private Foreign Direct Investments in OPEC Nations: From Public and Non-Public Policy Perspectives. Journal of Public Budgeting Accounting and Financial Management, 9, 331-355.

Omran, M., \& Bolbol, A. (2003). Foreign Direct Investment, Financial Development, and Economic Growth: Evidence from the Arab Countries. Review of Middle East Economics and Finance, 1(3), 231-249. http://dx.doi.org/10.1080/1475368032000158232

Omri, A., \& kahouli, B. (2014). The nexus among foreign investment, domestic capital and economic growth: Empirical evidence from the MENA region. Research in Economics, 68(3), 257-263. http://dx.doi.org/10. 1016/j.rie.2013.11.001

Onyeiwu, S. (2003). Analysis of FDI Flows to Developing Countries: Is the MEN a region Different? Paper Presented at the ERF 10th Annual Conference, December, Marrakech, Morocco.

Osinubi, T. S., \& Amaghionyeodiwe, L. A. (2009). Foreign Direct Investment and Exchange Rate Volatility in Nigeria. International Journal of Applied Econometrics and Quantitative Studies, 9(2), 83-116.

Pajunen, K. (2008). Institutions and Inflows of Foreign Direct Investment: A fuzzy-set Analysis. Journal of International Business Studies, 39(4), 652-669. http://dx.doi.org/10.1057/palgrave.jibs.8400371

Pan, W., \& Song, Y. (2014). Empirical analysis for the impact of RMB real effective exchange rate on foreign direct investment in China. Journal of Chemical \& Pharmaceutical Research, 6(5).

Parajuli, S., \& Kennedy, P. L. (2010). The Exchange Rate and Inward Foreign Direct Investment in Mexico. Paper Presented at the Southern Agricultural Association, Florida, USA.

Pradhan, A. K., \& Kelkar, S. (2014). Macroeconomic Determinants of Foreign Direct Investment in India: An Empirical Investigation (1991-2012). Jour. Comm. and Manag. Thou., 5(4), 530-544. http://dx.doi.org/10. 5958/0976-478X.2014.00002.0

Rajana, R. S., Rongalab, S., \& Ghoshc, R. (2008). Attracting Foreign Direct Investment (FDI) to India. World Scientific Press.

Salman, A., \& Feng, H. X. (2010). FDI in Pakistan: Impact on GNP and Capital Financial Account. 2010 International Conference on Financial Theory and Engineering. http://dx.doi.org/10.1109/ICFTE.2010. 5499389

Samimi, A. J., \& Rezanejad, A. G. Z. (2013). Financial Development, FDI and Governance in Mena Regio. Middle-East Journal of Scientific Research, 17(9), 1285-1289.

Schneider, F., \& Frey, B. S. (1985). Economic and Political Determinants of Foreign Direct Investment. World Development, 13(2), 161-175. http://dx.doi.org/10.1016/0305-750X(85)90002-6

Schneider, T., Ben Ltaifa, N., Ahmed, F., \& Chami, S. (2007). Yemen: Exchange Rate Policy in the Face of Dwindling Oil Exports. IMF Working Papers, 7(5), 1. http://dx.doi.org/10.5089/9781451865691.001

Shahzad, A., \& Al-Swidi, A. K. (2013). Effect of Macroeconomic Variables on the FDI inflows: The Moderating Role of Political Stability: An Evidence from Pakistan. Asian Social Science, 9(9). http://dx.doi.org/10.5539 
/ass.v9n9p270

Shahzad, A., Al-Swidi, A. K., Mithani, D. A., Bt Fadzil, F. H., \& Bin Golamuddin, A. G. (2012). An Empirical Investigation on The Effect of Business Environment Factors on The FDI Inflows in Pakistan: The Moderating Role of Political Stability. Business and Economic Research, 2(2). http://dx.doi.org/10.5296/ber. v2i2.2597

Sinani, E., \& Meyer, K. E. (2004). Spill overs of Technology Transfer from FDI: The Case of Estonia. Journal of Comparative Economics, 32(3), 445-466. http://dx.doi.org/10.1016/j.jce.2004.03.002

Singh, H., \& Jun, K. W. (1999). Some New Evidence on Determinants of Foreign Direct Investment in Developing Countries. Policy Research Working Papers. http://dx.doi.org/10.1596/1813-9450-1531

Solomon, B., \& Ruiz, I. (2012). Political Risk, Macroeconomic Uncertainty, and the Patterns of Foreign Direct Investment. The International Trade Journal, 26(2), 181-198. http://dx.doi.org/10.1080/08853908.2012. 657592

Temiz, D., \& Gökmen, A. (2014). FDI inflow as an international business operation by MNCs and economic growth: An empirical study on Turkey. International Business Review, 23(1), 145-154. http://dx.doi.org/10. 1016/j.ibusrev.2013.03.003

Toda, H. Y., \& Yamamoto, T. (1995). Statistical Inference in Vector Auto regressions with Possibly Integrated Processes. Journal of Econometrics, 66(1-2), 225-250. http://dx.doi.org/10.1016/0304-4076(94)01616-8

Todaro, \& Smith. (2011). Economic development todaro smith (11th ed.), 44.

UNCTAD. (2007). World Investment Report 2007: Transnational corporations, extractive industries and development. New York and Geneva: United Nations.

UNCTAD. (2009). World Investment Report 2009: Transnational Corporations, Agricultural Production and Development. New York and Geneva: United Nations.

UNCTAD. (2010). World Investment Report. United Nations, New York.

UNCTAD. (2011). World Investment Report. United Nations, New York.

UNCTAD. (2013). World Investment Report 2013: Transnational Corporations, Extractive Industries and Development. New York and Geneva: United Nations.

Vijayakumar, N., Sridharan, P., \& Rao, K. C. S. (2010). Determinants of FDI in BRICS Countries: A panel analysis. International Journal of Business Science and Applied Management, 5(3), 1-13.

Wang, M. (2009). Manufacturing FDI and economic growth: Evidence from Asian economies. Applied Economics, 41(8), 991-1002. http://dx.doi.org/10.1080/00036840601019059

Wheeler, D., \& Mody, A. (1992). International investment location decisions. Journal of International Economics, 33(1-2), 57-76. http://dx.doi.org/10.1016/0022-1996(92)90050-T

World Bank Report. (2006). United State, New York.

World Bank Report. (2011). United State, New York.

World Bank. (2013). Country Data: Link to Foreign Direct Investment definition. Retrieved from http://devdata.worldbank.org/external/CPProfile.asp?SelectedCountry=YEM\&CCODE=YEM\&CNAME=Y emen\%2C+Rep.\&PTYPE $=\mathrm{CP}$

Younis, M., Lin, X. X., Sharahili, Y., \& Selvarathi, S. (2008). Political Stability and Economic Growth in Asia. American J. of Applied Sciences, 5(3), 203-208. http://dx.doi.org/10.3844/ajassp.2008.203.208

\section{Copyrights}

Copyright for this article is retained by the author(s), with first publication rights granted to the journal.

This is an open-access article distributed under the terms and conditions of the Creative Commons Attribution license (http://creativecommons.org/licenses/by/3.0/). 